\title{
Lake Erie beaches: diel variation in fish assemblage structure and implications for monitoring
}

\author{
Scott M. Reid · Nicholas E. Mandrak
}

Received: 30 November 2007 / Revised: 27 June 2008/Accepted: 9 August 2008/Published online: 30 August 2008

(C) Springer Science+Business Media B.V. 2008

\begin{abstract}
Knowledge of temporal variation in nearshore Laurentian Great Lakes fish assemblages is important for understanding species-habitat associations, how abiotic and biotic influences vary temporally, and when sampling should occur. Using spring and fall seining data from Lake Erie beaches, we compared day and night fish assemblages and tested for differences among sampling periods. Beaches were utilized by a diverse collection of Lake Erie basin fishes (one-third of known species). During all sampling periods, catches were dominated by cyprinid species (53-91\%), and by invertivores and planktivorous fishes. Diel differences were detected in abundance, species richness and assemblage structure. Multivariate analyses (canonical analysis of principal coordinates) indicated that season had a larger influence on fish assemblage structure than diel period. Given observed temporal variation in assemblage structure, studies of Laurentian Great Lakes beach fishes should be restricted to a
\end{abstract}

Handling editor: J. Trexler

Electronic supplementary material The online version of this article (doi:10.1007/s10750-008-9571-1) contains supplementary material, which is available to authorized users.

S. M. Reid $(\square)$ - N. E. Mandrak

Great Lakes Laboratory for Fisheries and Aquatic

Sciences, Fisheries and Oceans Canada, Burlington, ON,

Canada L7R 4A6

e-mail: screid@trentu.ca single time period (e.g. day-time spring sampling), or adopt sampling designs that permit diel period and season to be included as factors in analyses. Second, the large seasonal variation in assemblage composition combined with higher night species richness indicates that night sampling during both spring and fall would be the most efficient and comprehensive approach for beach fish inventory.

Keywords Nearshore habitat - Temporal patterns . Great Lakes $\cdot$ Seine $\cdot$ Sampling

\section{Introduction}

Nearshore areas of the Laurentian Great Lakes are of special interest because of their linkages and interactions with large pelagic offshore habitats (Randall et al., 1996), and their important role in fish production and supporting biodiversity (Goforth \& Carman, 2003; Wei et al., 2004). It has been estimated that approximately $80 \%$ of Laurentian Great Lakes fishes use nearshore areas for at least part of the year (Chow-Fraser \& Albert, 1999). Beaches account for approximately $20 \%$ of the Laurentian Great Lakes shoreline (Wei et al., 2004), and provide important reproductive and nursery habitats for fishes (Heufelder et al., 1982; Wei et al., 2004). Groynes, jetties and breakwaters have extensively modified these habitats; leading to the loss of nearshore sand deposits and reduced size of beaches (Meadows 
et al., 2005). However, compared to coastal wetlands and other habitats, beach fish assemblages and the abiotic and biotic factors influencing their composition have been rarely investigated.

Diel variation in the composition of fish assemblages has been detected in the shallow, nearshore areas of a variety of freshwater and marine environments (Sanders, 1992; Pierce et al., 2001; Morrison et al., 2002; Blackwell \& Brown, 2005). Day and night differences in species associations with shallow, nearshore areas have been attributed to environmental gradients (i.e. oxygen concentration), feeding activity and predator avoidance (Emery, 1973; Helfman, 1981; Morrison et al., 2002; Wolter $\&$ Frehof, 2004). Diel patterns may also reflect differences in vulnerability to sampling gear (Pierce et al., 2001; Gries \& Letcher, 2002). Seining (the sampling gear employed in this study) is a common method for determining species distributions, and assessing the abundance and richness of small fishes in the nearshore areas of lakes (Blackwell \& Brown, 2005). However, compared to well-documented differences in day and night electrofishing catches, few studies have investigated the influence of diel period on beach seining results (Pierce et al., 2001).

The objective of this study was to compare day and night Lake Erie beach fish assemblages. Lake Erie is the 11th largest lake in world (surface area: $25,700 \mathrm{~km}^{2}$ ). It is the most biologically productive of the Laurentian Great Lakes; supporting the highest diversity of fishes (Coon, 1999). However, the Lake Erie ecosystem has been severely altered as a result of the combined effects of eutrophication, overexploitation of fishery resources, habitat degradation, pollution and invasive species (Koonce et al., 1996). Quantification of diel differences in Lake Erie beach fish assemblages is important for the: (1) characterization of how species and lifestages utilize different habitats (Morrison et al., 2002); (2) description of how abiotic and biotic influences on fish assemblage composition vary with time of sampling (Rundle \& Jackson, 1996); and (3) identification of appropriate sampling schedules for impact assessments and longterm monitoring of fish populations.

Using data from spring and fall seining of beaches across the north shore of Lake Erie, we tested for diel differences in fish abundance, species richness and beach fish assemblage structure. As diel variation in shallow habitat use can reflect patterns of feeding activity and predation risk, and feeding guilds are incorporated into indicators of aquatic ecosystem health, we also investigated temporal variation in the representation of feeding guilds.

\section{Materials and methods}

\section{Beach sampling}

In 2005 and 2006, 24 beach sites were sampled along the north shore of Lake Erie (Fig. 1). Beaches were distributed across the three Lake Erie basins: eastern basin $(n=6)$, central basin $(n=13)$ and western basin $(n=5)$. Most beaches sampled were located in municipal, provincial and federal parks, which ensured that sites were accessible for both day and night beach access. Sites sampled were a mix of sand and sand/gravel beaches with maximum sampled water depths between 0.5 and $1.5 \mathrm{~m}$. The ranges of spring and fall water temperatures were similar: 12.9 to $27.0^{\circ} \mathrm{C}$ and 12.5 to $25.0^{\circ} \mathrm{C}$, respectively. Measurements of conductivity and water clarity (secchi depth) ranged from 214 to $330 \mu \mathrm{sm}^{-1}$ and 0.04 to $1.2 \mathrm{~m}$, respectively.

At each site, $250 \mathrm{~m}$ of beach habitat were sampled with five consecutive $50 \mathrm{~m}$ long seine hauls pulled parallel along the shore's edge. The bag seine was $15.2 \times 2.4 \mathrm{~m}$ with a $2.4 \times 2.4 \times 2.4 \mathrm{~m}$ bag. Mesh size was $6.4 \mathrm{~mm}$ for the wings and $3.2 \mathrm{~mm}$ for the bag. Day and night sampling at each site was completed in the late spring (June 5th to 21st) and fall (September 27th to October 12th). Night sampling (after twilight) commenced after 2130 EDT in the spring, and after 1930 in the fall. Sites were sampled only during one season each year (i.e. spring 2005 and fall 2006, or spring 2006 and fall 2005). We were prevented from summer sampling because of high recreational beach use, and excessive amounts of filamentous algae (Cladophora) that quickly filled the bag seine.

\section{Data analysis}

For each season, we tested the effect of diel period on total fish abundance with a paired sample $t$-test (Zar, 1999). Diel differences in overall feeding guild structure were tested with a paired sample Hotelling's $t$-test (Hammer et al., 2001). A multivariate test was 
Fig. 1 Distribution of beach sites $(O)$ sampled across the north shore of Lake Erie $\left(42.2^{\circ} \mathrm{N}\right.$, $\left.81.2^{\circ} \mathrm{W}\right)$. Location of study area within the Laurentian Great Lakes basin is provided within the inset map

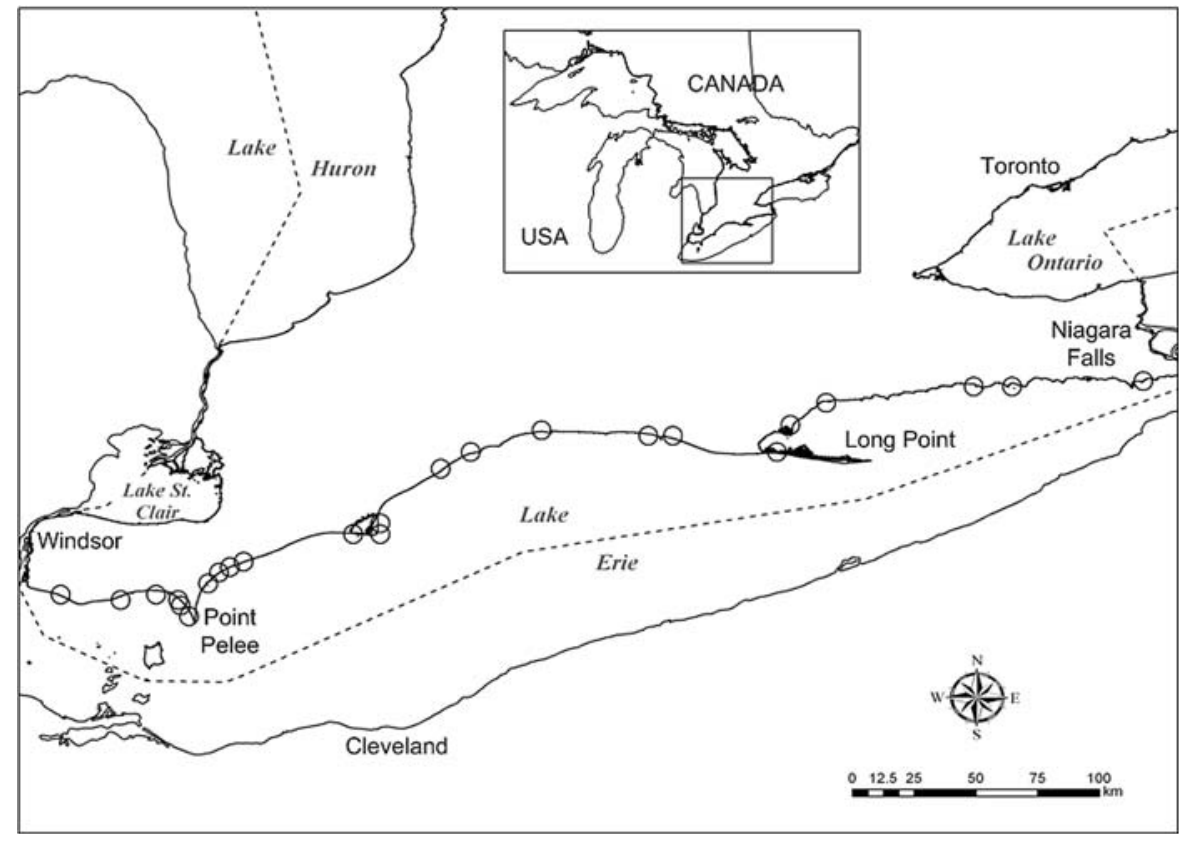

used because small-bodied species are expected to alter habitat use in the presence of piscivores (Diehl \& Eklov, 1995). Therefore, guilds cannot be considered as independent variables. Species were assigned to five different feeding guilds (detritivore, invertivore, omnivore, piscivore and planktivore) based on diet information in Jenkins \& Burkhead (1993), Scott \& Crossman (1973) and Thomas et al. (2005) (Appendix 1). Abundance data were log-transformed in order to normalize distributions before analysis.

Species-richness estimates are dependent on the number of individuals in each sample (Gotelli \& Colwell, 2001). Therefore, we constructed individualbased species rarefaction curves for the purpose of comparing species richness among different sampling periods (Estimate $S$ software: Colwell, 2005). Curves were constructed using a rarefaction-sampling algorithm, and repeated re-sampling of smaller number of individuals from the larger dataset (Estimate $S$ software, Colwell, 2005).

Metric multidimensional scaling (MDS) and canonical analysis of principal coordinates (CAP) (Anderson, 2004) were used to graphically display and test for differences in fish assemblage structure among sampling periods. Analyses tested for diel differences within each season, and for differences among all sampling periods. CAP is a constrained ordination method that displays multivariate data by reference to specific a priori hypotheses (Anderson \& Willis, 2003). It has been shown to better discriminate spatial and temporal differences in fish assemblage datasets than unconstrained ordination methods (e.g. non metric dimensional scaling, nMDS) (Anderson \& Willis, 2003, Williams et al., 2008). Two test statistics, $\delta^{2}$ and a Trace statistic, were calculated (using 9999 random permutations) to determine if differences existed among sampling periods. Classification success (calculated using the 'leave-one-out' method) was used to evaluate group distinctiveness in multivariate space (Anderson \& Willis, 2003). Minimum misclassification error was the criterion used to select the number of principal coordinate axes (within each season: $m=1$; all sampling periods: $m=4$ ). Abundance data were logtransformed and the Bray-Curtis distance measure was used in the analysis. Species present at $<5 \%$ of sites sampled were not included in the analysis (Gauch, 1982), as rare species can have a disproportionate effect on multivariate analysis (Jackson \& Harvey, 1989).

Species responsible for differences among sampling periods in CAP plots were identified by the strength of their correlation with canonical discriminant axes (Anderson \& Willis, 2003). Species with correlations of $|r|>0.4$ and frequencies of occurrence $>40 \%$ were considered influential (Willis et al., 
2006). Differences in the abundance of influential species among sampling periods were tested with paired sample $t$-tests (between diel periods), and twoway ANOVA without replication (among all sampling periods) (Sokal \& Rohlf, 1995; Zar, 1999). For significant ANOVA results, differences among sampling periods were tested with post-hoc Tukey HSD tests. Abundance data were square-root, or logtransformed to normalize distributions.

Species distribution data are often spatially autocorrelated, which can create problems for statistical tests that assume independence of error terms (Hinch et al., 1994; Legendre \& Legendre, 1998). To evaluate the influence of spatial autocorrelation, correlations between a Euclidian geographic distance (UTM site co-ordinates) matrix and site-by-species abundance distance (Bray-Curtis) matrices for each sampling period were calculated using a Mantel test (10,000 permutations).

\section{Results}

\section{Species composition}

In the spring, 57,417 individuals representing 36 species were seined from Lake Erie beaches. During the fall, 19,624 individuals representing 38 species were captured. In total, 43 species from 15 fish families were collected. Scientific names, relative abundance and frequency of occurrence of all fishes are presented in Appendix 1. The most abundant and widespread species were brook silverside (Labidesthes sicculus (Cope)), emerald shiner (Notropis atherinoides Rafinesque), mimic shiner (N. volucellus (Cope)), round goby (Neogobius melanostomus (Pallus)), spottail shiner (N. hudsonius (Clinton)) and white perch (Morone Americana (Gmelin)) (Appendix 1). During all sampling periods, seine hauls were dominated by cyprinid species (53-91\% of individuals). Emerald shiner was the most common species; captured at more than $98 \%$ of sites sampled and constituting 36-79\% of the total catch. Individually, most species captured in seine hauls represented $<2 \%$ of the total catch.

While seine hauls were generally dominated by small-bodied schooling fishes (e.g. Cyprinidae and Atherinidae), two species listed by the Committee on the Status of Endangered Wildlife in Canada (channel darter (Percina copelandi (Jordan)): Threatened, and orangespotted sunfish (Lepomis humilis (Girard)): Special Concern) (COSEWIC, 2006), 13 recreationally and commercially-important fishes, and nine introduced and invasive species (alewife (Alosa pseudoharengus (Wilson)), brown trout (Salmo trutta Linnaeus), common carp (Cyprinus carpio Linnaeus), goldfish (Carassius auratus auratus (Linnaeus)), rainbow smelt (Osmerus mordax mordax (Mitchill)), rainbow trout (Oncorhynchus mykiss (Walbaum)), round goby, tubenose goby (Proterorhinus marmoratus (Pallus)) and white perch were also captured.

Abundance and species richness

Diel period had a significant effect on the total number of fish captured during beach seining (spring: $t=2.0, P=0.05$; fall: $t=2.5, P=0.02$ ); with more fish being captured during the day (Fig. 2). Rarefaction curves indicate that species richness was higher during night sampling (both seasons), and during fall sampling (both diel periods) (Fig. 3). Beach fish assemblages were dominated by invertivores (18-50\%) and planktivorous species (38-79\%) (Fig. 4). Despite large diel differences in the mean abundance of invertivores and planktivores (Fig. 4), overall guild structure was not significantly different between sampling periods (spring: $T^{2}=14.5$, $P=0.14$; fall: $\left.T^{2}=16.5, P=0.10\right)$. Sampling was not designed to test for differences among year in CPUE or species richness. However, qualitative comparisons of mean CPUE data (total fish abundance, and species number) indicate that differences

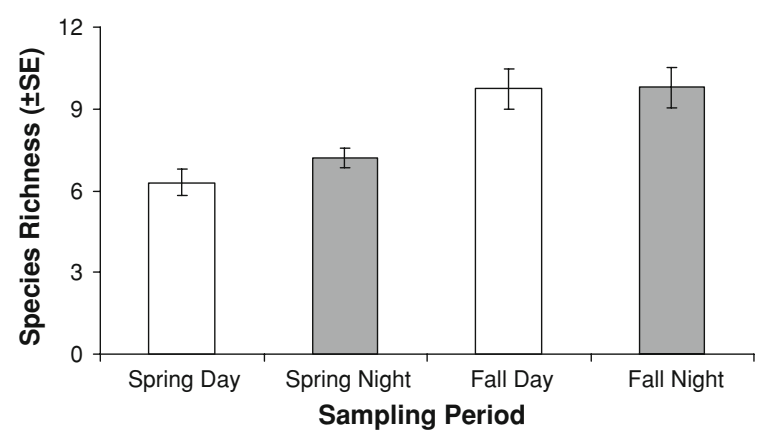

Fig. 2 Comparison of Lake Erie beach mean ( \pm standard error) fish total abundance and species richness across different sampling periods 

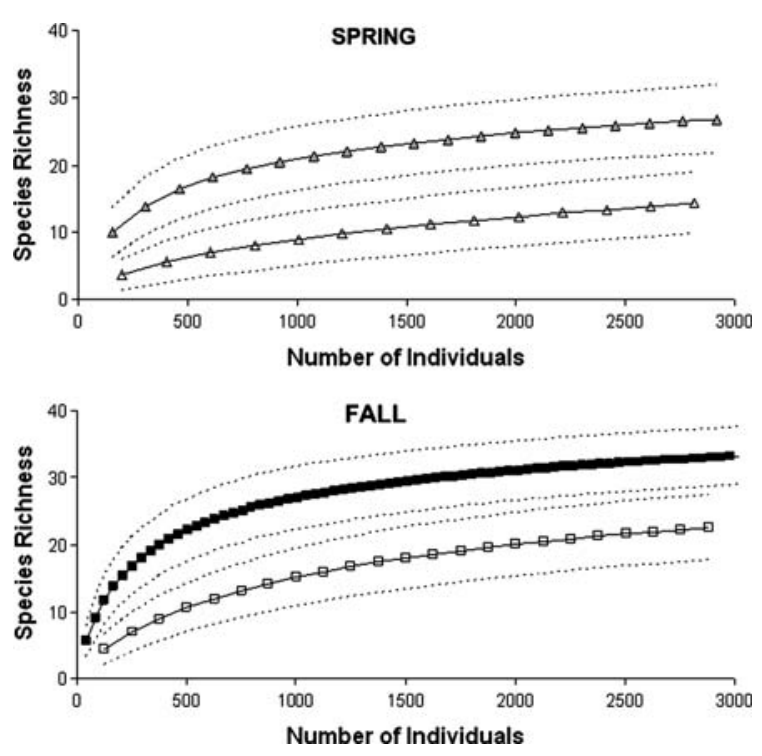

Fig. 3 Spring and fall individual-based species rarefaction curves ( $\pm 95 \% \mathrm{CI}$ ) calculated from day (spring: $\Delta$; fall: $\square$ ) and night (spring: $\boldsymbol{\Delta}$; fall: $\mathbf{\square}$ ) seining data
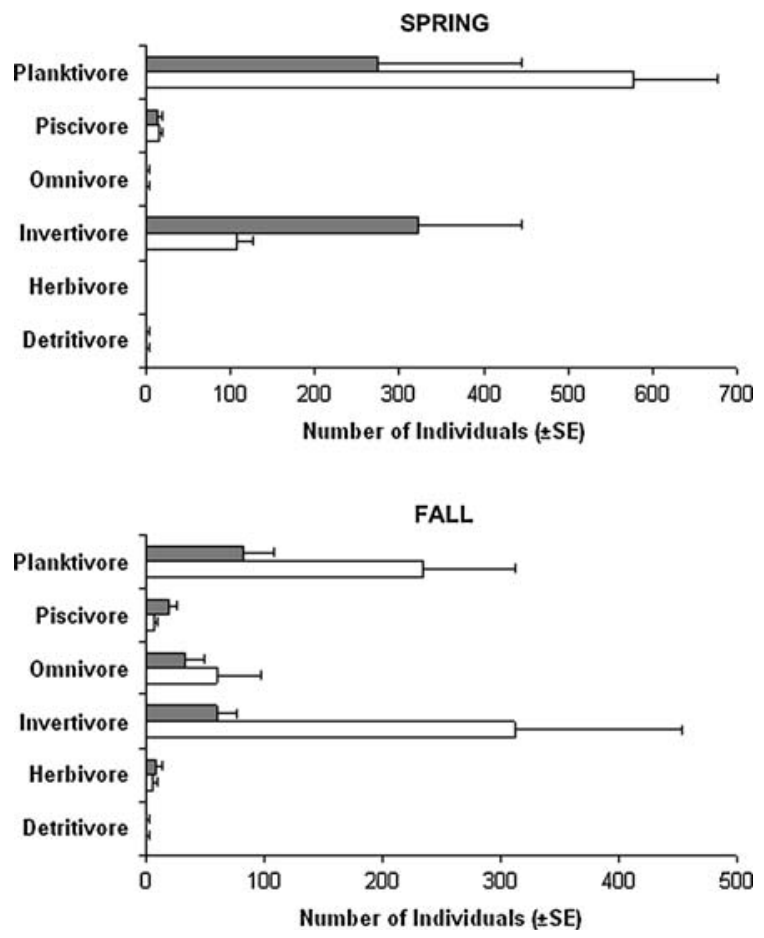

Fig. 4 Comparison of mean number of individuals representing different feeding guilds across different sampling periods (day: $\square$; night:

between groups of sites sampled on different years were consistent across diel periods and seasons (Reid \& Mandrak, unpublished data).
Temporal variation in fish assemblage structure

Significant canonical test statistics $(P=0.0001)$ indicate that the structure of beach fish assemblages differed between diel periods (spring: Trace $=0.39$; $\delta^{2}=0.39$; fall: Trace $=0.41 ; \delta^{2}=0.41$ ) (Fig. 5), and among all sampling periods (Trace $=0.93$; $\delta^{2}=0.72$ ) (Fig. 6). The 'leave-one-out' method indicated some overlap among sampling periods; with misclassification rates of $25 \%$ (spring), $27 \%$ (fall) and 33\% (all sampling periods). Spatial autocorrelation within the fish assemblage dataset was not detected for any of the sampling periods $(P>0.2)$.

Correlations between individual species abundance and canonical axes indicate that diel differences resulted from variation in the abundance of alewife (fall), brook silverside (spring and fall), emerald shiner (fall), mimic shiner (spring), round goby (spring), spottail shiner (spring) and white perch (fall) (Table 1). Catches of brook silverside, emerald shiner, mimic shiner and spottail shiner were greater during day seining, while alewife, round goby and white perch were more abundant at night. Diel differences were significant (range of $t$-statistics: 4.4 to $4.4, P<0.05$ ) for most species. However, differences in emerald shiner $(t=1.9, P=0.07)$ and spottail shiner $(t=1.8, P=0.08)$ abundance were only marginally significant. Other species characterized by diel differences in abundance and site occurrence, but having lower correlations with CAP axes, included quillback (Carpoides cyprinus (Lesueur)), spotfin shiner (Cyprinella spiloptera (Clinton)), trout-perch (Percopsis omiscomaycus (Walbaum)) and white bass (Appendix 1).

Constrained ordination (CAP) of site-species data from all sampling periods resulted in greater separation between seasons than diel periods, and a greater separation between sampling periods than the unconstrained ordination (metric MDS) (Fig. 6). Clear seasonal differences are evident along the first canonical axis. Species with correlations greater than $10.4 \mid$ with the first axis include alewife, brook silverside, pumpkinseed and round goby. For all four species, there were significant differences in CPUE between seasons (range of $F$-statistics: 5.7 to 32.3, $P<0.01$ ) (Table 2). Catches of round goby were greater during spring seining, while, alewife, brook silverside and pumpkinseed were more abundant in the fall. Separation along the second canonical axis 
Fig. 5 Diel comparisons of unconstrained (top: metric MDS) and constrained (bottom: CAP) ordinations of Lake Erie beach fish assemblage data collected during spring (day: $\Delta$; night: $\mathbf{\Delta}$ ) and fall (day: $\square$; night: $\mathbf{\square})$ seining. Ordinations were calculated using the Bray-Curtis distance measure and logtransformed species abundance data
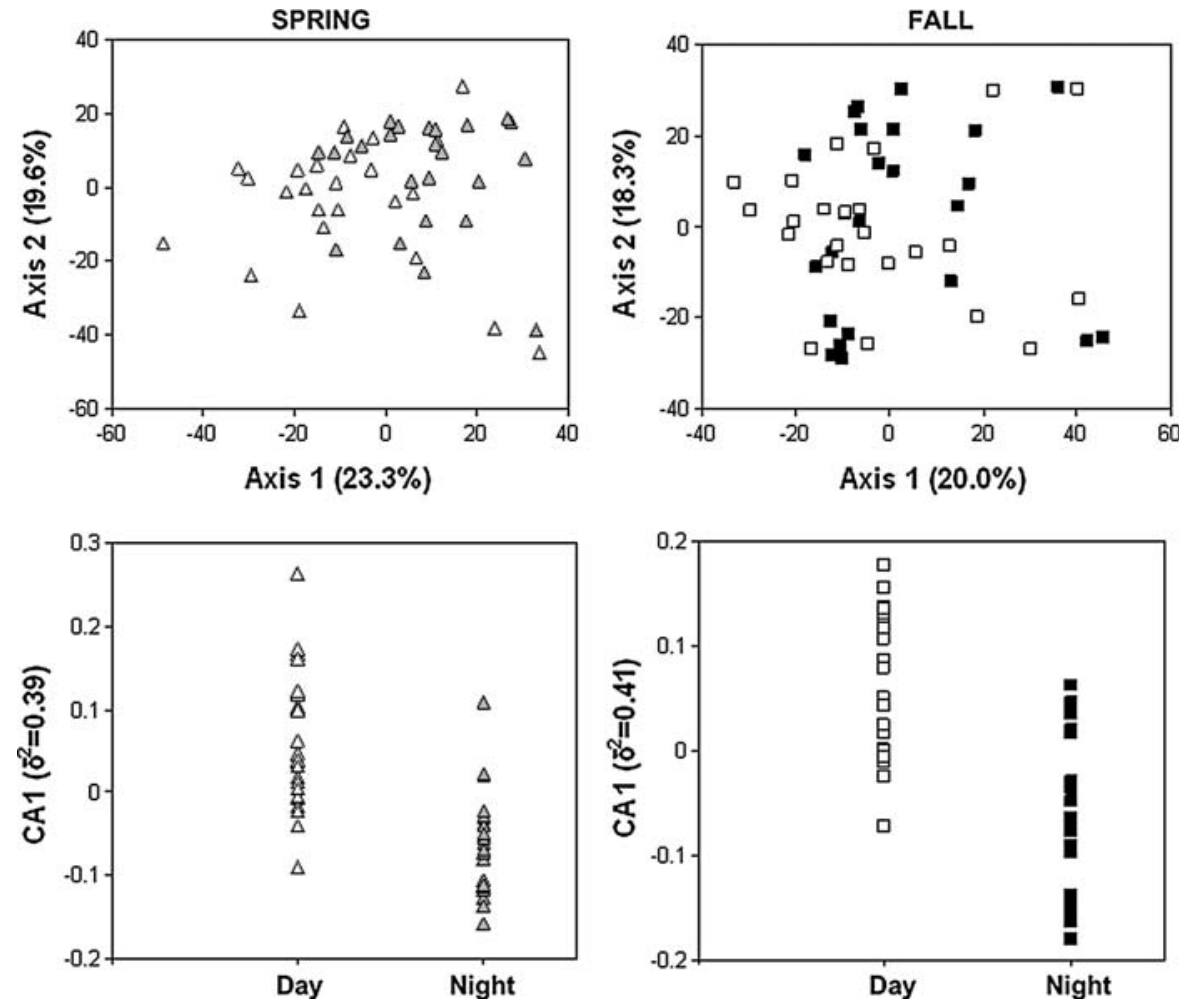

reflected differences in diel period (Fig. 6). Species with axis correlations greater than $|0.4|$ included emerald shiner and mimic shiner. Significant differences in CPUE among sampling periods were identified for both species (emerald shiner: $F=2.8$, $P=0.04$; mimic shiner: $F=7.2, P<0.001$ ). However, differences based on diel period were not as consistent as the seasonal differences identified for species correlated with the first canonical axis (Table 2).

\section{Discussion}

Beaches and other nearshore Laurentian Great Lakes habitats have historically been perceived as "wet deserts" that support few species of interest (MacKey $\&$ Goforth, 2005). In our study, one-third of the fish species known from the Lake Erie basin (Van Meter \& Trautman, 1970; Coon, 1999) were captured from north shore beaches, including species-at-risk, and recreationally and commercially important species. This diversity of fishes provide evidence of the importance of these habitats for both permanent resident fishes and more wide-ranging species that may only use beaches for feeding or spawning. Fish assemblages were similar in composition and diversity to beach seine collections from the south shore of eastern Lake Erie (Diers et al., 2001), and most species are also found along the lower reaches of Lake Erie tributaries (Sharma \& Jackson, 2007). The numerical dominance of small-bodied schooling species, and invertivores and planktivorous species was consistent with descriptions of Lake Michigan beach fishes (Brazner and Beals, 1997).

Diel patterns of total fish abundance, species richness and assemblage structure were detected at Lake Erie beaches. Differences between day and night use of shallow nearshore habitats have been explained in terms of diel variation in fish behaviour (e.g. feeding, activity levels, schooling behaviour and association with cover) (Emery, 1973; Helfman, 1981). Night-time increases in the number of alewife, quillback, round goby, trout-perch and white bass were consistent with the observations of Emery (1973), Jude et al. (1992), Sanders (1992) and Pierce et al. (2001). Fewer mimic shiners in shallow nearshore habitats at night have also been previously reported by Helfman (1981). The lack of strong diel differences for most fishes caught in this study is, 

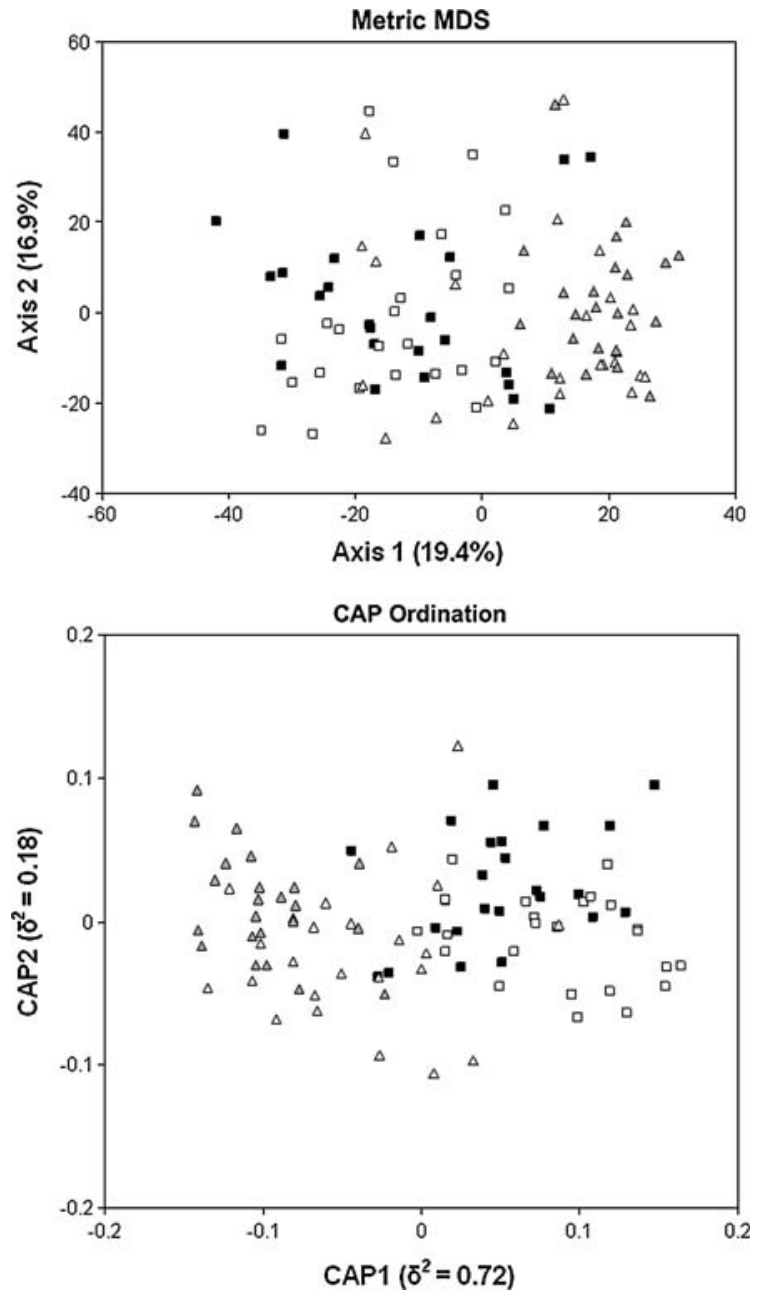

Fig. 6 Unconstrained (top: metric MDS) and constrained (bottom: CAP) ordinations of Lake Erie beach fish assemblage data from all sampling periods (spring day: $\Delta$; spring night: $\boldsymbol{\Lambda}$; fall day: $\square$; fall night: $\mathbf{\square}$ ). Ordinations were calculated using the Bray-Curtis distance measure and log-transformed species abundance data

however, consistent with the collections of Diers et al. (2001). This pattern may be attributable to the: (1) rarity of most fishes captured; (2) high among-site variability in catch (e.g. emerald shiner and spottail shiner) reducing the statistical power of comparisons (Zar, 1999); (3) similar catchability of fishes during day and night seining (Pierce et al., 2001); or (4) the lack of large diel differences in piscivore abundance.

Constrained ordination (CAP) indicated that season had a larger influence on the composition of Lake Erie beach fish assemblages than diel period. Large seasonal differences have been detected in trapnet
Table 1 Comparison of mean ( \pm standard error) day and night CPUE (fish per site) of species identified by the CAP procedure to influence diel differences in beach fish assemblage structure

\begin{tabular}{llrcr}
\hline Season & Species & \multicolumn{1}{c}{$\begin{array}{l}\text { Day } \\
\text { CPUE }\end{array}$} & \multicolumn{1}{l}{$\begin{array}{l}\text { Night } \\
\text { CPUE }\end{array}$} \\
\hline Spring & $\begin{array}{l}\text { Brook } \\
\text { silverside }\end{array}$ & 0.46 & $2.3 \pm 1.0$ & $0.54 \pm 0.38$ \\
& Mimic shiner & 0.73 & $145.0 \pm 104.9$ & $4.4 \pm 2.7$ \\
& Round goby & -0.46 & $2.5 \pm 1.2$ & $12.9 \pm 4.9$ \\
& Spottail shiner & -0.44 & $84.9 \pm 34.7$ & $22.7 \pm 4.9$ \\
Fall & Alewife & 0.43 & $0.21 \pm 0.12$ & $8.2 \pm 6.2$ \\
& Brook & 0.49 & $264.3 \pm 120.9$ & $19.3 \pm 8.7$ \\
& silverside & & & \\
& Emerald shiner & 0.43 & $224.7 \pm 77.8$ & $79.4 \pm 25.6$ \\
& White perch & -0.47 & $4.1 \pm 1.3$ & $13.3 \pm 5.7$ \\
\hline
\end{tabular}

Species correlations $(r)$ with canonical discriminant axes are also presented

catches of nearshore fishes from Long Point Bay, Lake Erie (Hamly \& Howley, 1985). Seasonal patterns in the use of nearshore areas vary in response to the timing of spawning behaviour, the recruitment of juveniles, ontogenetic changes in diet and predation risk, and seasonal changes to habitat characteristics (Lyons, 1987; Hatzenbeler et al., 2000). Shifts in fish assemblage structure have also been linked to seasonal changes in macrophyte cover (Hatzenbeler et al., 2000), dissolved oxygen gradients (Tonn \& Magnuson, 1982), and the littoral thermal regime (Lyons, 1987; Reyjol et al., 2005). In the nearshore habitats of Lake Ontario, Tufescu (1994) found onshore and offshore migrations of pelagic species (and their predators) to correspond with the beginning and end of lake thermal stratification. While spring-fall differences in total abundance, species richness and fish assemblage structure existed, seasonal differences in the abundance of individual species were limited to a few species: alewife (more abundant in the fall), brook silverside (more abundant in the fall) and round goby (more abundant in the spring). Seasonal variation has been previously reported for all three species (Jenkins \& Burkhead, 1993; Charlebois, 1997; Pyron \& Billman, 2007), and attributed to seasonal movements to spawning and over-wintering habitat, and to the recruitment of young-of-year from offshore areas.

When studying factors responsible for fish assemblage structure, knowledge of the scale (temporal or 
Table 2 Seasonal and diel comparison of mean ( \pm standard error) CPUE (fish per site) of species identified by the CAP procedure to influence differences in beach fish assemblage structure among all sampling periods

\begin{tabular}{|c|c|c|c|c|c|}
\hline \multirow[t]{2}{*}{ Species } & \multirow[t]{2}{*}{$r$} & \multicolumn{2}{|l|}{ Spring } & \multicolumn{2}{|l|}{ Fall } \\
\hline & & Day CPUE & Night CPUE & Day CPUE & Night CPUE \\
\hline Alewife & $0.41^{\mathrm{a}}$ & $0 \pm 0^{\mathrm{A}}$ & $0 \pm 0^{\mathrm{A}}$ & $0.2 \pm 0.1^{\mathrm{B}}$ & $8.2 \pm 6.2^{\mathrm{C}}$ \\
\hline Brook silverside & $0.75^{\mathrm{a}}$ & $2.3 \pm 1.0^{\mathrm{A}}$ & $0.5 \pm 0.4^{\mathrm{A}}$ & $264.3 \pm 120.9^{\mathrm{B}}$ & $19.3 \pm 8.7^{\mathrm{C}}$ \\
\hline Pumpkinseed & $0.48^{\mathrm{a}}$ & $0.2 \pm 0.1^{\mathrm{A}}$ & $0.2 \pm 0.1^{\mathrm{A}}$ & $0.7 \pm 0.2^{\mathrm{B}}$ & $1.0 \pm 0.3^{\mathrm{B}}$ \\
\hline Round goby & $-0.61^{\mathrm{a}}$ & $2.5 \pm 1.2^{\mathrm{A}}$ & $12.9 \pm 4.9^{\mathrm{B}}$ & $1.0 \pm 0.2^{\mathrm{C}}$ & $1.4 \pm 0.1^{\mathrm{C}}$ \\
\hline Emerald shiner & $-0.68^{b}$ & $482.5 \pm 145.8^{\mathrm{A}}$ & $279.6 \pm 103.8^{\mathrm{A}, \mathrm{B}}$ & $224.7 \pm 77.8^{\mathrm{A}, \mathrm{B}}$ & $79.4 \pm 25.6^{\mathrm{B}}$ \\
\hline Mimic shiner & $-0.44^{\mathrm{b}}$ & $145.0 \pm 104.9^{\mathrm{A}}$ & $4.4 \pm 2.7^{\mathrm{B}}$ & $36.1 \pm 24.3^{\mathrm{A}, \mathrm{B}}$ & $10.4 \pm 5.1^{\mathrm{B}}$ \\
\hline
\end{tabular}

Species correlations $(r)$ with canonical discriminant axes are also presented (canonical axes are identified by superscripts a and b). Significant differences in CPUE among sampling periods (based on Tukey HSD test, $P<0.05$ ) are indicated by superscripts (e.g. A and $\mathrm{B}$ indicate significantly different values)

spatial) at which variation dominates is important for determining appropriate sampling periods (Pierce et al., 2001), and whether data can be pooled across scales (Rundle \& Jackson, 1996). In this study, season has a strong effect on the ordination of fish assemblages. This result is in agreement with Pyron \& Billman (2007) who also found season to have a significant effect based on nearshore seining data from Presque Isle Bay, Lake Erie. Diel period also affected the ordination of beach fish assemblages but less than season. Given the temporal variation detected in this study, it is recommended that interpretations of the influence of abiotic and biotic factors on Laurentian Great Lakes beach fish assemblages be limited to data collected during a singletime period (e.g. spring day seining), or data that permit diel period and season to be included as separate factors in subsequent analyses.

Observed temporal variation also has implications for species inventories of Laurentian Great Lakes beaches and long-term monitoring programs. Based on species accumulation curves derived from the same Lake Erie dataset, Reid \& Mandrak (In Press) concluded that night sampling was more efficient at species detection, and provided a more complete species list than day sampling. Pooling day and night samples resulted in only a slight (2\%) improvement in species detection. Therefore, considering the large seasonal variation in assemblage composition, night sampling during both spring and fall is expected to be the most efficient and comprehensive approach for beach fish inventory and monitoring.

Since its introduction into the lower Laurentian Great Lakes, round goby has been implicated in the decline of native benthic fishes (French \& Jude, 2001; Baker, 2005), and in the predation of eggs and juveniles of other fishes (Charlebois et al., 1997; Steinhart et al., 2004). Monitoring round goby population and distribution trends, and associated ecosystem impacts requires knowledge of appropriate sampling periods and the suitability of gear types for different habitats (Johnson et al., 2005; Diana et al., 2006). Given the range of water depths utilized by round goby and their preference for rocky substrates, seining has not been considered as an effective sampling method for round goby (Johnson et al., 2005; Diana et al., 2006). However, in this study, beach seining was effective at: (1) detecting the presence of round goby at all beaches sampled; (2) identifying diel and seasonal trends in abundance and (3) collecting multiple age classes of round goby (range of total lengths: $20-160 \mathrm{~mm}$ ). While the capture of large numbers of round goby from sandy nearshore areas is not typical with that of most Laurentian Great Lakes studies, it has been reported for sandy nearshore habitats in the Gulf of Gdansk, Baltic Sea (Corkum et al., 2004).

Compared to other freshwater ecosystems, the ecology of nearshore areas in the Laurentian Great Lakes is still in its infancy (MacKey \& Goforth, 2005). Results from this study indicate that Lake Erie beaches are utilized by a diverse collection of fishes, and that large temporal variation (diel and seasonal) in assemblage composition exists. Our understanding of the factors structuring beach fish assemblages would be further improved by investigating the influence of site characteristics (i.e. substrate, water depth and wave exposure), and the loss and 
modification of beaches by shoreline protection structures (e.g. groynes, jetties and breakwaters). Additionally, observed temporal variation in beach fish assemblage structure indicates that time of sampling is an important consideration for future monitoring and research programs. The design of these programs would further benefit from an assessment of different gear types to detect and measure the relative abundance of beach fishes (Pierce et al., 2001; Tran, 2007).

Acknowledgements The study was supported by Fisheries and Oceans Canada, Interdepartmental Recovery Fund, and the Ontario Ministry of Natural Resources. Field sampling was assisted by J. Barnucz, A. Dextrase, S. Dobbyn, A. Drake, A. Edwards, D. Marsen, and M. Nelson. Comments provided by J. Trexler, and three anonymous reviewers greatly improved earlier versions of the manuscript.

\section{References}

Anderson, M. J., 2004. CAP: A FORTRAN Computer Program for Canonical Analysis of Principal Coordinates [Available from the Internet URL http://www.stat.auckland. ac.nz/ mja].

Anderson, M. J. \& T. J. Willis, 2003. Canonical analysis of principal coordinates: a useful method of constrained ordination for ecology. Ecology 84: 511-525.

Baker, K., 2005. Nine year study of the invasion of western Lake Erie by the round goby (Neogobius melanostomus): changes in goby and darter abundance. Ohio Journal of Science 105: A-31.

Blackwell, B. G. \& M. L. Brown, 2005. Comparison of day and night shoreline seine catches in two South Dakota glacial lakes. Journal of Freshwater Ecology 20: 79-83.

Brazner, J. C. \& E. W. Beals, 1997. Patterns in fish assemblages from coastal wetland and beach habitats in Green Bay, Lake Michigan: a multivariate analysis of abiotic and biotic forcing factors. Canadian Journal of Fisheries and Aquatic Sciences 54: 1743-1761.

Charlebois, P. M., J. E. Marsden, R. G. Goettel, R. F. Wolfe, D. J. Jude \& S. Rudnicka, 1997. The round goby, Neogobius melanostomus (Pallus), a review of European and North American literature. Illinois-Indiana Sea Grant Program and Illinois Natural History Survey. INHS Special Publication No. 20, Urbana.

Chow-Fraser, P. \& D. Albert, 1999. Biodiversity investment areas for coastal wetland systems. In State of the Great Lakes Ecosystem Conference 1998. US Environmental Protection Agency and Environment Canada, Buffalo.

Colwell, R. K., 2005. Estimate S: Statistical Estimation of Species Richness and Shared Species from Samples. Version 7.5. [Available from the Internet URL http://viceroy.eeb.uconn.edu/EstimateS].
Coon, T. G., 1999. Icthyofauna of the Great Lakes. In Taylor, W. W. \& C. P. Ferrari (eds), Great Lakes Fisheries Policy and Management. Michigan State University Press, East Lansing: 55-72.

Corkum, L. D., M. R. Sapota \& K. E. Skora, 2004. The round goby, Neogobius melanostomus, a fish invader on both sides of the Atlantic Ocean. Biological Invasions 6: 173-181.

COSEWIC, 2006. Canadian Species at Risk. Committee on the Status of Endangered Wildlife in Canada, Ottawa.

Diana, C. M., J. L. Jonas, R. M. Claramunt, J. D. Fitzsimmons \& J. E. Marsden, 2006. A comparison of methods for sampling round goby in rock littoral areas. North American Journal of Fisheries Management 26: 514-522.

Diehl, S. \& P. Eklov, 1995. Effects of piscivore mediated habitat use on resources, diet and growth of perch. Ecology 76: 1712-1726.

Diers, J. A., D. Einhouse \& D. R. Orvos, 2001. Characterization of eastern Lake Erie inshore fish communities. Great Lakes Research Review 5: 6-10.

Emery, A. R., 1973. Preliminary comparisons of day and night habits of freshwater fish in Ontario lakes. Journal of the Fisheries Research Board of Canada 30: 761-774.

French III, J. R. P. \& D. J. Jude, 2001. Diets and diet overlap of nonindigenous gobies and small benthic native fishes coinhabiting the St. Clair River, Michigan. Journal of Great Lakes Research 27: 300-311.

Gauch, H. G., 1982. Multivariate Analysis in Community Ecology. Cambridge University Press, Cambridge.

Goforth, R. R. \& S. M. Carman, 2003. Research, assessment, and data needs to promote protection of Great Lakes nearshore fisheries habitat. Michigan State University Extension Report No. 2003-11, East Lansing.

Gotelli, N. J. \& R. K. Colwell, 2001. Quantifying biodiversity: procedures and pitfalls in the measurement and comparison of species richness. Ecology Letters 4: 379-391.

Gries, G. \& B. H. Letcher, 2002. A night seining technique for juvenile Atlantic salmon in streams. North American Journal of Fisheries Management 22: 595-601.

Hamly, J. M. \& T. P. Howley, 1985. Factors affecting variability of trapnet catches. Canadian Journal of Fisheries and Aquatic Sciences 42: 1079-1087.

Hammer, Ø., D. A. T. Harper \& P. D. Ryan, 2001. PAST: paleontological statistics software package for education and data analysis. Paleontologia Electronica 4: 1-9.

Hatzenbeler, G. R., M. A. Bozek, M. J. Jennings \& E. E. Emmons, 2000. Seasonal variation in fish assemblage structure and habitat structure in the nearshore littoral zone of Wisconsin lakes. North American Journal of Fisheries Management 20: 360-368.

Helfman, G. S., 1981. Twilight activities and temporal structure in a freshwater fish community. Canadian Journal of Fisheries and Aquatic Sciences 38: 1405-1420.

Heufelder, G. H., D. J. Jude \& T. J. Tesar, 1982. Cold-water upwelling effects on abundance and distribution of larval alewives (Alosa pseudoharengus) in eastern Lake Michigan. Canadian Journal of Fisheries and Aquatic Sciences 39: 1531-1537.

Hinch, S. G., K. M. Somers \& N. C. Collins, 1994. Spatial autocorrelation and the assessment of habitat-abundance 
relationships in littoral fish. Canadian Journal of Fisheries and Aquatic Sciences 51: 701-712.

Jackson, D. A. \& H. Harvey, 1989. Biogeographic associations in fish assemblages: local vs. regional processes. Ecology 70: $1472-1484$.

Jenkins, R. E. \& N. M. Burkhead, 1993. Freshwater Fishes of Virginia. American Fisheries Society, Bethesda.

Johnson, T. B., M. Allen, L. D. Corkum \& V. A. Lee, 2005. Comparison of methods needed to estimate population size of round gobies (Neogobius melanostomus) in western Lake Erie. Journal of Great Lakes Research 31: 78-86.

Jude, D. J., R. H. Reider \& G. R. Smith, 1992. Establishment of Gobiidae in the Great Lakes basin. Canadian Journal of Fisheries and Aquatic Sciences 49: 416-421.

Koonce, J. F., W. D. N. Busch \& T. Czopla, 1996. Restoration of Lake Erie: contribution of water quality and natural resource management. Canadian Journal of Fisheries and Aquatic Sciences 53(Supplement 1): 105-112.

Legendre, P. \& L. Legendre, 1998. Numerical Ecology. Elsevier Science BV, Amsterdam.

Lyons, J., 1987. Distribution, abundance and mortality of small littoral-zone fishes in Sparkling Lake, Wisconsin. Environmental Biology of Fishes 18: 93-107.

MacKey, S. D. \& R. R. Goforth, 2005. Great Lakes nearshore habitat science. Journal of Great Lakes Research 31(Supplement 1): 1-5.

Meadows, G. A., S. D. MacKey, R. R. Goforth, D. M. Mickelson, T. B. Edil, J. Fuller, D. E. Guy Jr, L. A. Meadows, E. Brown, S. M. Carman \& D. L. Liebenthal, 2005. Cumulative habitat impacts of nearshore engineering. Journal of Great Lakes Research 31(Supplement 1): 90-112.

Morrison, M. A., M. P. Francis, B. W. Hartill \& D. M. Parkinson, 2002. Diurnal and tidal variations in the abundance of the fish fauna of a temperate tidal mudflat. Estuarine and Coastal Shelf Science 54: 793-807.

Pierce, C. L., A. M. Corcoran, A. N. Gronbach, S. Hsia, B. J. Mullarkey \& A. J. Schwartzhoff, 2001. Influence of diel period on electrofishing and beach seining assessments of littoral fish assemblages. North American Journal of Fisheries Management 21: 918-926.

Pyron, M. \& E. J. Billman, 2007. Fish assemblages of open lake coastal wetlands in Presque Isle Bay, Lake Erie. In Simon, T. P. \& D. M. Stewart (eds), Coastal Wetlands of the Laurentian Great Lakes: Health Habitat and Indicators. CRC Press, Boca Raton: 489-496.

Randall, R. G., C. K. Minns, V. W. Cairns \& J. E. Moore, 1996. The relationship between an index of fish production and submerged macrophytes and other habitat features at three littoral areas in the Great Lakes. Canadian Journal of Fisheries and Aquatic Sciences 53(Supplement 1): 35-44.

Reid, S. M. \& N. E. Mandrak, In Press. Effect of diel period on seining effort required to detect changes in Lake Erie beach fish assemblages. Environmental Monitoring and Assessment. doi:10.1007/s10661-008-0337-z.

Reyjol, Y., P. Fischer, S. Lek, R. Rosch \& R. Eckman, 2005. Studying the spatiotemporal variation of the littoral fish community in a large prealpine lake using self-organizing mapping. Canadian Journal of Fisheries and Aquatic Sciences 62: 2294-2302.

Rundle, H. D. \& D. A. Jackson, 1996. Spatial and temporal variation in littoral-zone fish communities: a new statistical approach. Canadian Journal of Fisheries and Aquatic Sciences 53: 2167-2176.

Sanders, R. E., 1992. Day versus night electrofishing catches from near-shore waters of the Ohio and Muskingum Rivers. Ohio Journal of Science 92: 51-59.

Scott, W. B. \& E. J. Crossman, 1973. Freshwater fishes of Canada. Bulletin 184. Fisheries Research Board of Canada, Ottawa.

Sharma, S. \& D. A. Jackson, 2007. Fish assemblages and environmental conditions in the lower reaches of northeastern Lake Erie tributaries. Journal of Great Lakes Research 33: 15-27.

Sokal, R. R. \& F. J. Rohlf, 1995. Biometry, 3rd ed. W. H. Freeman \& Company, New York.

Steinhart, G. B., E. A. Marschall \& R. A. Stein, 2004. Round goby predation on smallmouth bass offspring in nests during experimental catch and release angling. Transactions of the American Fisheries Society 133: 121-131.

Thomas, J. A., E. B. Emery \& F. H. McCormick, 2005. Detection of temporal trends in Ohio River fish assemblages based on lock chamber surveys (1957-2001). American Fisheries Society Symposium 45: 431-450.

Tonn, W. M. \& J. J. Magnuson, 1982. Patterns in the species composition and richness of fish assemblages in northern Wisconsin lakes. Ecology 63: 1149-1166.

Tran, J. L., 2007. Nearshore small fishes of Lake Huron: maximizing detection of species in sampling surveys, demography of an invasive species, round goby, and nest defense of native smallmouth bass against round gobies. M.Sc. Thesis. University of Toronto, Toronto.

Tufescu, M. V. A., 1994. Seasonal variation patterns of the fish community in the littoral waters of northern Lake Ontario, the Pickering-Darlington area. Hydrobiologia 281: 141-154.

Van Meter, H. D. \& M. B. Trautman, 1970. An annotated list of the fishes of Lake Erie and its tributary waters exclusive of the Detroit River. Ohio Journal of Science 70: 65-78.

Wei, A., P. Chow-Fraser \& D. Albert, 2004. Influence of shoreline features on fish distribution in the Laurentian Great Lakes. Canadian Journal of Fisheries and Aquatic Sciences 61: 1113-1123.

Williams, G. J., M. J. Cameron, J. R. Turner \& R. B. Ford, 2008. Quantitative characterization of reef fish diversity among nearshore habitats in a northeastern New Zealand marine reserve. New Zealand Journal of Marine and Freshwater Research 42: 33-46.

Willis, T. J., F. Badalamenti \& M. Milazzo, 2006. Diel variability in counts of reef fishes and its implications for monitoring. Journal of Experimental Marine Biology and Ecology 331: 108-120.

Wolter, C. \& J. Frehof, 2004. Diel distribution patterns of fishes in a temperate large lowland river. Journal of Fish Biology 64: 632-642.

Zar, J. H., 1999. Biostatistical Analysis, 4th ed. Prentice-Hall, New Jersey. 